\title{
Sünnet Sonrası Prilokaine Bağlı Toksik Methemoglobinemide Oral Metilen Mavisi ve İntravenöz Askorbik Asit ile Hızlı Tedavi: Bir Olgu Sunumu
}

\author{
Using Methylene Blue and Intravenous Ascorbic Acid Quick Therapy in Prilocaine Depen- \\ dent Toxic Methaemoglobinemia after Circumcision: A Case Report
}

\section{Muhammet Mesut Nezir ENGİN ${ }^{1}$, Nefise Arıbaş ÖZ ${ }^{1}$, Yunus ŞENGÜN ${ }^{1}$, Furkan TIMUR ${ }^{1}$, Kenan KOCABAY ${ }^{2}$}

${ }^{1}$ Ar. Gör. Dr. Düzce Üniversitesi Tip Fakültesi Çocuk Sağlığı ve Hastalıkları Anabilim Dalı, DÜZCE
${ }^{2}$ Prof. Dr. Düzce Üniversitesi Tıp Fakültesi Çocuk Sağlığı ve Hastalıkları Anabilim Dalı, DÜZCE

Özet

Prilokain, pek çok alanda kullanılan lokal anestetik bir ajandır, ancak hayatı tehdit edebilen bir yan etki olan methemoglobinemiye neden olabilmektedir. Bunun sonucunda dokularda hipoksiye neden olur. Bu olgu sunumunda 66 günlük erkek bir bebek tartışılmıştır. Cerrahi girişim sonrasında siyanoz gelişen ve $\mathrm{pO} 2$ ile $\mathrm{SaO} 2$ değerleri arasında uyumsuzluk saptanan hastalarda methemoglobinemi düşünülmelidir. Böyle durumlarda hastalar gelişebilecek problemler açısından tam donanımlı çocuk yoğun bakım ünitelerinde izlenmelidir.

Anahtar Kelimeler: Küçük cerrahi işlem, methemoglobinemi, prilokain, askorbik asit

\section{Abstract}

Prilocain is a commonly used local anaesthetic, but its side effect, called methemoglobinemia, can cause death. This leads to hypoxia in the tissues.In this case report, we discussed a 66 days old male baby. Methemoglobinemia should be considered in patients who develop cyanosis after surgery and discordance between $\mathrm{pO} 2$ and $\mathrm{SaO} 2$ values. These patients should be observed in fully equipped pediatric intensive care units for precaution.

Key Words: Small surgical process, methaemoglobinemia, prilocaine, ascorbic acid

\section{GİRIŞ}

Hemoglobin $(\mathrm{Hb})$ eritrositlerde bulunan ve dokulara oksijen $\left(\mathrm{O}_{2}\right)$ taşınmasını sağlayan bir moleküldür. Normal koşullarda Hb'de bulunan demir ferröz formdadır, yani iki değerliklidir. Hb’deki demirin çesitli oksidatif streslerle okside olup, üç değerlikli ferri $(\mathrm{Fe}+++)$ formuna geçmesiyle methemoglobinemi oluşur (1). Methemoglobin, $\mathrm{O}_{2}$ taşıyamaz ve yaptığı etkilerle hemoglobin-oksijen dissosiasyon eğrisini sola kaydırarak dokulara daha zor $\mathrm{O}_{2}$ verilmesine yol açar. Normal şartlarda methemoglobin total Hb'nin \%1'i kadardır ve \%2-\%3'ünü geçmez. Fizyolojik olarak bireylerde oksidan maddelerle temas sonrası oluşabilen methemoglobin, eritrositlerde bulunan NADH sitokrom b5 redüktaz enzim sistemi sayesinde düşük tutulabilmektedir (1). Bu çalışmada, sünnet öncesi analjezik amaçlı prilokain ile dorsal penil sinir bloğu (DPSB) uygulanan, sonrasında akut methemoglobinemi gelişen, bir saat sonra morarma yakınması ile tarafımıza konsülte edilen ve çocuk yoğun bakım ünitemize yatırılan 66 günlük erkek hastanın vakası sunularak akut methemoglobineminin siyanozun ayırıcı tanısında düşünülmesi gerekliliği ve tedavi yöntemleri gözden geçirilmiştir.

\section{OLGU SUNUMU}

Üroloji servisinde 66 günlük erkek hastaya sünnet öncesi DPSB amaciyla $1.5 \mathrm{mg} / \mathrm{kg}$ prilokain (Citanest $^{\circ}$ $\% 0.5)$ yapildiktan sonra serviste takip edilirken genel durum bozukluğu, huzursuzluk ve santral siyanozu olması nedeniyle tarafımıza konsülte edildi. Hastanın öyküsünden 38. gestasyonel hafta da sezaryenle $3500 \mathrm{gr}$ ağırlığında doğduğu, sünnet planlandığ 1 ve 66 günlük sürede başka bir sağlık problemi olmadığı öğrenildi. Ailede methemoglobinemi öyküsü bulunmadığ öğrenildi. Hasta takip ve tedavi amaçlı çocuk yoğun bakım ünitesine yatırıldı. İlk başvuruda yapılan fizik muayenesinde (Resim 1) genel durumu kötü olan hastamız huzursuzdu, cilt ve mukozaları siyanotik görünümde ve solunum sistemi muayenesi doğaldı. Kardiyak muayene normaldi. Hastanın kan basınc1 108/57 mmHg, nabiz 157/dakika, solunum sayıs1 52/ dakika ve pulse oksimetre ile oksijen saturasyonu \% 84

Bu çalışma 60. milli pediatri kongresinde bildiri olarak sunulmuştur ( 8 -13 Kasım 2016 Antalya)

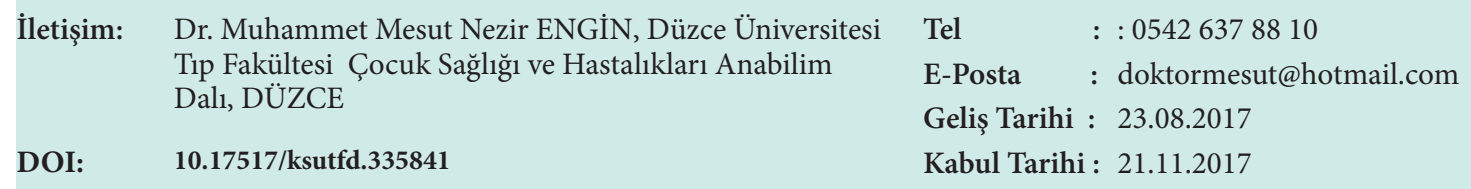


saptandi. Hastadan başvuru sırasında alınan kan gazında pH: 7.34 (7,35-7,45), HCO3: $17 \mathrm{mEq} / \mathrm{L}$ (22-26), $\mathrm{pCO}_{2}$ : $27,5 \mathrm{mmHg}(35-45)$ ve methemoglobin düzeyi $\% 41,4$ (0-1,5) olarak saptandı. Hastanın ilk başvuruda nazal $\mathrm{O}_{2}$ ile satürasyonları yükselmedi. Hastadan bakılan kan tetkikinde Hemoglobin: 9,6 g/dL (10-17), lökosit: 22 bin/ uL (3-15), Hematokrit: \% 29,2 (26-50), Trombosit: 340 bin/uL (150-400), CRP: 0,10 mg/dL (0-0,5), Glukoz: 179 olarak saptandı ve diğer laboratuvar değerleri normaldi.

Resim 1: Tedavi öncesi, hastanın cildi siyanotik görünümde

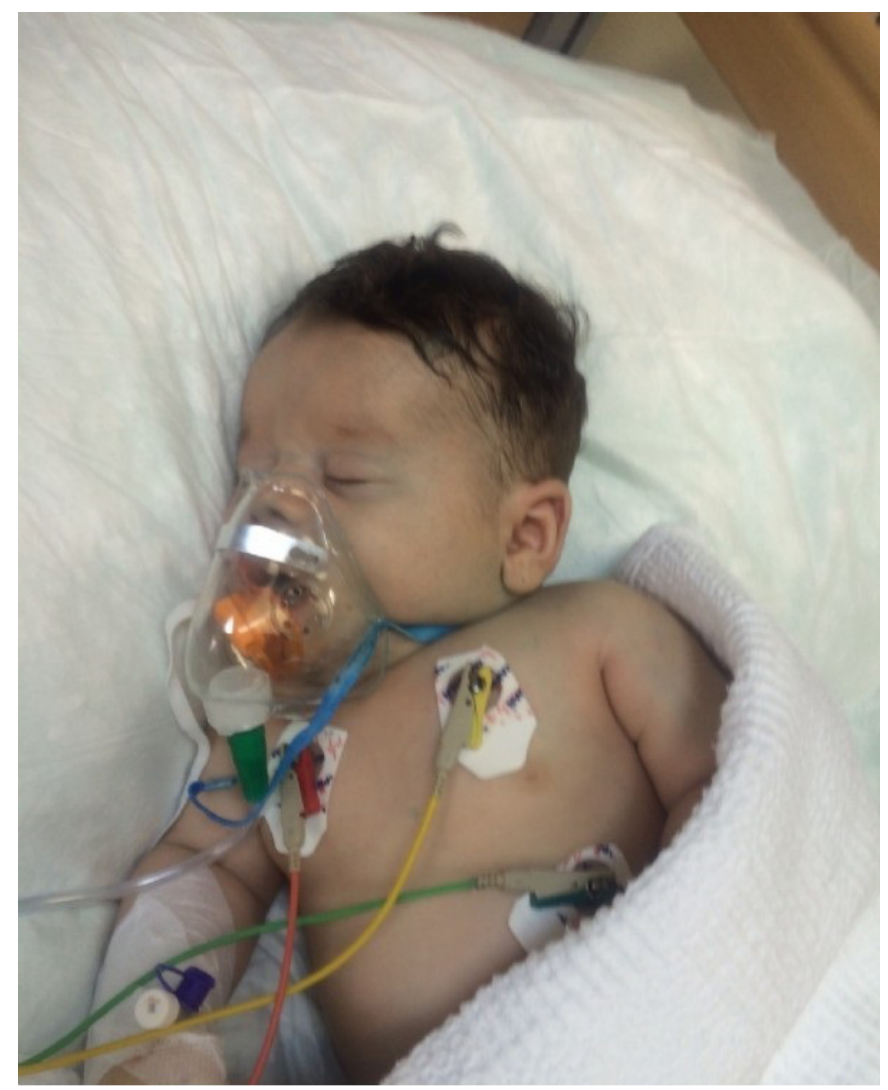

Hastaya $1 \mathrm{mg} / \mathrm{kg}$ 'dan oral metilen mavisi, $300 \mathrm{mg} /$ kg' dan IV Askorbik asit, 10 lt/dk maske ile oksijen ve 1500 cc/m2'den $1 / 4$ serum fizyolojik (\%5 dekstrozlu) başlandı. İzleminin 2. saatinde hastanın genel durumu iyi, kan basinc1 113/82 mmHg, nabiz 131/dakika, solunum say1s1 56/dakika ve pulse oksimetre ile oksijen saturasyonu oksijenli \% 97 saptand.

Hastadan alınan kan gazında $\mathrm{pH}: 7,33, \mathrm{HCO} 3:$ $18,9 \mathrm{mEq} / \mathrm{L}, \mathrm{pCO}_{2}: 35,8 \mathrm{mmHg}$ ve methemoglobin oran 1 $\%$ 2,4 olarak sonuçlandı. İzleminin 4.saatinde solunum sayısı 44/dakika'ya geriledi. Hastanın pulse oksimetre ile oksijen saturasyonu oksijensiz \% 96 olarak gözlendi. Siyanozu düzelen ve ek komplikasyon gelişmeyen hasta şifa ile taburcu edildi (Resim 2).

\section{TARTIŞMA}

Methemoglobinemi kalitsal veya edinsel nedenlerle oluşabilmektedir. Otozomal resesif kalıtılan çeşitli enzim sistemlerindeki konjenital bozukluklara bağlı dört tip herediter methemoglobinemi görülebilir. Edinsel methemoglobinemiye sebep olan kimyasal madde ve ilaçlar arasında; nitritler, nitratlar, kloratlar, kininler, aminobenzenler, nitrobenzenler, nitrotoluenler, fenasetin, klorokin, dapson, fenitoin, sülfonamidler ve lokal anestetikler sayılabilir (2).

Guayve ark. 242 olguluklokal anestezik kullanımına bağlı methemoglobinemi görülen serilerinde kullanılan ilaçlar, prilokain, benzokain, lidokain ve tetrakaindir (3). Bunların içinde çocuklarda en sık methemoglobinemi yapan ilaç \% 54 ile prilokaindir. Literatürde prilokainin terapotik dozlarda kullanımına bağlı methemoglobinemi gelişimi de bildirilmiştir (4).

\section{Resim 1: Tedavi sonrası, hastanın siyanozu düzeldi}

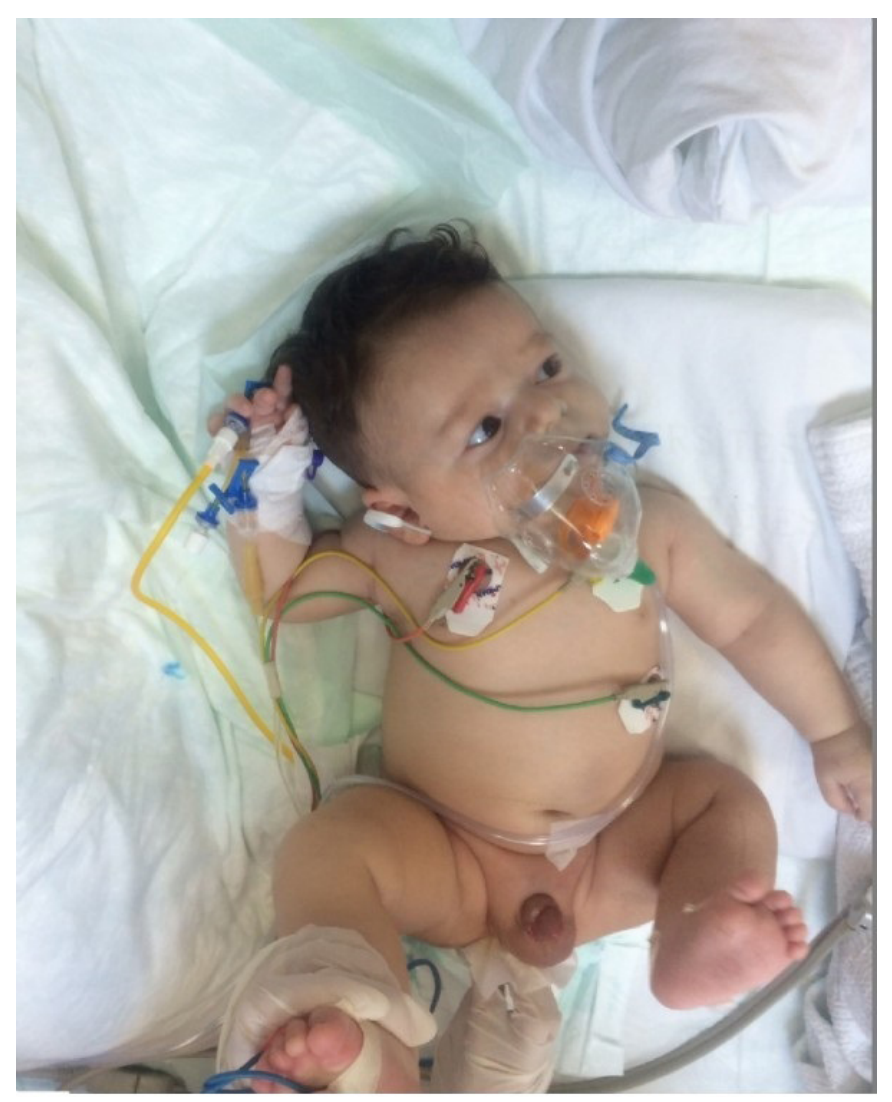

Hafif olgular genellikle asemptomatik olabilmekle birlikte; ciddi olgularda siyanoz, taşikardi, takipne, hipotansiyon, konfüzyon ve hatta ölüm görülebilir. Kandaki methemoglobin düzeyi ile orantılı olarak siyanoz saptanabilmektedir. Methemoglobin düzeyi \% 10 'u aşınca periferik siyanoz saptanmaya başlar, \% 35 ve üzeri değerlerde doku hipoksisi ile birlikte yaygın siyanoz görülür iken; düzey \% 70'e ulaştığında koma tablosu gelişir ve bu durum tedavi edilmediğinde ölümle sonuçlanabilir $(1,3)$. Bizim olgumuzda \% 41 olarak saptandı, hastamızın santral siyanozu mevcuttu.

İnfantlarda gastrik pH'nın yüksek olmasının yanı sıra nitratı nitrite çeviren bakteri proliferasyonu da bağırsakta daha fazladır. Nitrit varlığında $\mathrm{Hb}$, methemoglobine daha kolay çevrilir. İnfantlarda methemoglobini hemoglobine çeviren sitokrom b5 redüktaz aktivitesi erişkinlerin yarısından azdır. Ayrıca bebeklerde daha fazla olan hemoglobin F hemoglobin A'ya göre oksidasyona daha duyarlıdır (5). Bizim hastamızda da görüldüğü üzere infantlar methemoglobinemiye bu sebeplerden dolayı daha yatkındır.

Literatürü taradığımız da altı aydan küçük bebeklerde $2 \mathrm{mg} / \mathrm{kg}^{\prime} \mathrm{dan}$ verilen prilokainin methemoglobinemiye neden olduğunu görmekteyiz 
(3). Küçük çocuklarda özellikle ilk üç aylık dönemde bupivakainin daha güvenilir bir lokal anestezik olduğu birçok çalışmada bildirilmiştir (1-6).

Prilokain, metaboliti olan orto-toluidin birikerek Hb'de bulunan iki değerlikli ferro $(\mathrm{Fe}++)$ demiri okside edip üç değerlikli ferri $(\mathrm{Fe}+++)$ demire dönüştürerek methemoglobinemiye yol açar (7).

Pratik uygulamada prilokainin enjektabl formu $\left(\right.$ Citanest $\left.^{\ominus}\right)$ ve prilokain-lidokain kremi $\left(\right.$ EMLA $\left.^{\circ}\right)$ kullanılmaktadır. Tedavi edici dozlardaki (1-2 mg/kg) prilokain, genelde, siyanoza yol açmayacak kadar düşük düzeylerde methemoglobin oluşumuna neden olmakta, doz arttıkça methemoglobinemi riski de artmaktadır (7).

Methemoglobinin yarı ömrü 55 dakika olup methemoglobinemi oluşumu ilacın alımından 20-60 dakika içerisinde oluşmaya başlar (8). Bizim olgumuzda da klinik bulgular 1 saat sonra görülmeye başlanmıştır.

Fizyolojik olarak kanda az miktarda oluşan methemoglobin, eritrositlerde NADH-methemoglobin redüktaz (sitokrom b5 redüktaz) ile hemen yıkılır. Kalıtsal olarak methemoglobinemi görüldüğünde, eritrosit $\mathrm{NADH}$-methemoglobin redüktaz eksikliği veya $\mathrm{M}$ hemoglobin varlığına bağlı olarak gelişebilir, yaşam boyu süren bir sorundur. Başka bir methemoglobin redüktaz sistemi de eritrositlerde NADPH'yi kofaktör olarak kullanır. Bu enzim normalde inaktiftir, belirli redoks bileşikleri varlığında aktif duruma geçer; NADPH'den aldığı elektronu methemoglobine aktararak molekülü indirger. Metilen mavisinin methemoglobinemi tedavisindeki etkisi bu mekanizma iledir (9).

$\mathrm{NADPH}$ oluşabilmesi için heksoz monofosfat şantı gereklidir; bu da G6PD düzeyinin normal sınırlarda olmasına bağlıdır (9). Bundan dolayı metilen mavisi G6PD eksikliğinde methemoglobinemiyi artırır ve dispne, göğüs ağrısı, tremor, siyanoz ve hemolitik anemiye neden olabileceğinden kontrendikedir. $\mathrm{Bu}$ durumda tedavide askorbik asit kullanılabilir. Askorbik asit methemoglobini in vitro olarak enzimatik olmayan yoldan indirger (1).

Tanıda methemoglobinemi düzeyini kan gazı tetkikiyle görebilmekteyiz. Basit bir laboratuar testi olarak Gutrie kağıdına damlatılan bir damla taze kanın çikolata renginde olması da tanıyı destekler (10).

Öztürk ve ark. Sünnet sonrası prilokaine bağlı methemoglobinemi gelişen ve düzeyi $\% 38,1$ olan hastaya Ankara Refik Saydam Hıfzısıha Enstitiüsü’nden elde edilen IV metilen mavisi uygulaması sonrası iyileşme sağlandığını bildirmişlerdir (1). Bizim hastamıza hastanemizde IV metilen mavisi bulunmadığ 1 için oral metilen mavisi ve askorbik asit verilmesi sonrasinda iyileşme gözlendi. Bizim olgumuzda olduğu gibi metilen mavisinin IV formu bulunamadığında oral formunun verilebileceği akılda tutulmalıdır.
Hastamızın methemoglobin düzeyi \% 41,4 idi, hastamıza verilen sıvı, oksijen, metilen mavisi ve askorbik asit tedavileri ile hızlı bir şekilde iki saat sonra düzelme gözlendi. Konca ve ark. hastaya oksijen, askorbik asit ve \% 5 dekstroz içeren mayi tedavisi ile 24 saat sonra düzelme olduğunu bildirmişlerdir (3).

Küçük cerrahi işlem sonrası siyanoz ile başvuran dolaşım ve solunum sistem bulguları normal olan hastada methemoglobinemi ayıricı tanılar arasinda düşünülmelidir (7).

Sonuç olarak bizim vakamızda da olduğu gibi metilen mavisi, askorbik asit ve oksijen birlikte verildiğinde hızlı bir şekilde iyileşme görülmektedir. İnfantlar methemoglobin oluşumuna yatkın olduğundan, ilk üç ayda daha güvenilir bir lokal anestezik olan bupivakain kullanılması önerilebilir.

\section{KAYNAKLAR}

1. Öztürk E, Turalı Aktaş B, Öztarhan K, Adal E. Lokal anestezik uygulaması sonrası gelişen methemoglobinemi. JOPP Derg 2010; 2: 46-8,

2. Coleman MD, Coleman NA. Drug induced methaemoglobinemia. Drug Safety 1996; 14: 394405.

3. Konca Ç, Kahramaner Z, Çoban M, Mahanoğlu Y, Tekin M, Turgut M. Edinsel methemoglobinemi olgusu. Güncel Pediatri 2014; 1: 54-7

4. Kumar AR, Dunn N, Naqvi M. Methemoglobinemia associated with a prilocainelidocaine cream. Clin Pediatr 1997; 36: 239-240.

5. Ergül Y, Nişli K, Kalkandelen S, Dindar A. Acute cyanosis after transcatheter balloon valvuloplasty: toxic methemoglobinemia due to local prilocaine use. Turk Kardiyol Dern Ars 2011; 39: 64-67.

6. Gunter JB. Benefit and risks of local anesthetics in infants and children. Paediatr Drugs 2002; 4: 649-72.

7. Kara A, Yigit S, Aygün C, Oran O. Prilokaine bağl1 toksik methemoglobinemide intravenöz askorbik asit kullanımı. Çocuk Sağlığı ve Hastalıkları Dergisi 2005; 48: 65-689.

8. Gülgün M, Kul M, Sarici SÜ, Alpay F. Prilokaine Bağlı Methemoglobinemi iki Olgu Sunumu ve Literatüre Bakış. Erciyes Tip Dergisi 2007; 29: 322-5.

9. Mansouri A. Methemoglobinemia. Am J Med Sci 1985; 289: 200-209.

10. Yurttutan S, Öncel MY, Özdemir R, Canpolat FE, Erdeve Ö, Dilmen U. Methemoglobinemi tedavisinde metilen mavisi kullanılan bir yenidoğanda ciddi hemolize bağlı sarılık: Olgu sunumu. JinekolojiObstetrik ve Neonatoloji Tip Dergisi 2012; 8: 1391-2 